\title{
Factors That Affect Students' Reticence in Class
}

\author{
Nguyen Van Tuyen \\ University of Foreign Language Studies, University of Danang, \\ 131 Luong Nhu Hoc St., Da Nang City, Vietnam \\ Corresponding e-mail: nvtuyen@ufl.udn.vn
}

\begin{abstract}
It is a widely held axiom that language is intertwined with culture. That is why teachers of languages and researchers show their concern about not only teaching methods but also culture of learning by language learners. In pursuit of empowering their learners' communicative competence in the target language, teachers need to invest as much as possible into their performance, including being flexible in class management, being mindful of their students' cultural behaviors or pedagogical psychology, etc., so that they can help learners' language skills to be enhanced further. However, it is well-documented that teachers of English and even of other subjects in Asia often complain continually about their students' reticence in class. In seeking to shed further light on the causal factors of reticence occurring in classes of students majoring in English at a University, the researcher of this mini research bases on cultural identity, power distance, and collectivists' culture of teaching and learning as conceptual frameworks. The methods applied for data analysis are qualitative and quantitative. The paper found that if students are reluctant to work orally in class, the real purpose of language teaching and learning cannot be fulfilled. Interaction among students as well as between the teacher and students is recommended to be maximized for the sake of communicative language learning.
\end{abstract}

Keywords: reticence, culture, language competence, identity, interaction

\section{INTRODUCTION}

It is a widely held axiom that language is intertwined with culture. That is why teachers of languages and researchers show their concern about not only teaching methods but also the culture of learning by language learners. In pursuit of empowering their learners' communicative competence in the target language, teachers need to invest as much as possible into their performance, including being flexible in class management, being mindful of their students' cultural behaviors or pedagogical psychology. Effective teachers' performance can help their learners' language skills to be enhanced further. One of the issues that teachers regularly think of is how to teach so that interaction among students as well as between teacher and students is maximized for the sake of communicative language learning. However, it is well-documented that teachers of English and even of other subjects in Vietnam often complain continually about their students' reticence in class. This is regarded as more negative than positive for the goal of communicative language learning. Recent research into Vietnamese students' competence in English speaking skill shows that they rank too low in comparison with other regional countries, despite their better skills at reading and writing. It is also known that the purpose of learning a language is to use it rather than just to learn about it. If students are reluctant to work orally in class, the real purpose of language teaching and learning cannot be fulfilled. So in seeking to shed further light on the causal factors of reticence occurring in classes of students majoring in English, the researcher of this mini research bases on cultural identity, power distance, and collectivists' culture of teaching and learning as conceptual frameworks. 
"Reticence is a communication problem with cognitive, affective, and behavioral dimensions and is due to the belief that one is better off remaining silent than risking appearing foolish" (Keaten \& Kelly, 2000). According to Li and Lui (2011), reticent individuals tend to avoid communication in social and public contexts, particularly novel situations that have the potential for negative evaluation. Keaten and Kelly (2000) agree that reticence is related to the category of foreign language anxiety, "which stands for the feeling of uneasiness, worry, nervousness and apprehension experienced by non-native speakers when learning or using a second or foreign language." These feelings may derived from any second language context whether associated with the four language macro skills. Research also find that reticent individuals who find themselves as incompetent communicators, and measured against norms about appropriate levels of talkativeness in social situations, and that reticence is typified by a set of faulty beliefs about communication, for example, competent communicators speak spontaneously and one must be born with good communication skills. Reticent individuals fear negative evaluation and appear foolish, and they have to learn to associate anxiety with communication (ibid). Although not extensively researched, reticence has been receiving increasing attention in recent decades due to the growing importance of oral proficiency in secondand foreign-language learning situations.

Researchers such as Allwright and Bailey, (1991); Chaudron, (1988); Tsui, (1996) found the relationship between reluctance to speak in class and a variety of factors including cultural beliefs regarding communication and the role of the teacher and learner, educational background, fear of being unable to be understood, shyness, the expectations and the comprehensibility of input provided by the instructor. These factors may not operate in isolation and as van Worde (2003, p.5) affirms, are likely to be intertwined (as cited in Donald, 2010, p.42). Donald shows his concern about learners' reticence as follows:

"Establishing an unambiguous relationship between reticence and language acquisition is also problematic due to the emic nature of the condition; learners may internalize the reasons they have for not speaking in class and practitioners are the constructors of the input learners receive, via lesson plans, teaching material and the language used for instruction. Therefore, for practitioners to gain a greater understanding of the conditions that contribute to reticence in the learners in their charge, it is necessary to gain an etic perspective and investigate the problem from the point of view of learners as well as to evaluate their own practice as the constructor of that practice." (p.42)

Learners' failure to use the target language in class to communicate in the class may also "engender in the instructor false assumptions regarding the ability of the learner, particularly if the instructor is a native speaker of the target language" (as cited in Cheng, 2000, p.438). The instructor may then pay more attention to those who appear better able to use the target language which may cause some reticent learners to believe that it is not worthwhile to contribute in class (ibid).

Jones (1999) conducted a survey and found that $60 \%$ of the staff respondents viewed Asian students (...) as quiet and inactive in class and reported much better communication with Australian, American, and European students. Ferris and Tagg (1996) investigated college and university professors' view of ESL students' difficulties with academic listening and speaking tasks and found that students need to overcome cultural inhibition or shyness about speaking up in class, to learn to ask and answer questions effectively. Tsui (1996) asked $38 \mathrm{ESL}$ teachers in Hong Kong and found that over $70 \%$ of them identified getting more student oral response as one of their major problems. Besides, Biggs (1996) summarized some misconceptions of the so-called Confucian heritage cultures, one of which is that "Asian students typically take a low profile, rarely asking questions or volunteer answers, let alone making public observations or criticism of course content." Tudor (1998) concludes that the reality of language teaching [and learning] emerges from a dynamic interaction of individual and sociocultural rationalities, a process in which is unique to each classroom and which can rarely be predicted in advance. Language learning is an extremely complex process, which is further complicated by the learners' individual differences and their different social, political and cultural background (Cheng, 2000).

Power distance (Hofstede, 1994) also affects students' reticence in class. Dahl (2003) pointed out that students in large power distance or collectivist societies are expected to show respect to their teachers by keeping silent and just listening. Nunan (1999) endorsed "all cultures have their own concepts of teaching, learning and education" (p.4). It can be inferred from the writer's statement that learners' and teachers' culture of learning and teaching can cause students' reticence in class. The next part of this research will go into more details to seek the answer how culture can affect the reticence of students in class. 


\section{METHODS}

The research is based on the combination of qualitative and quantitative method, and the collected data are analyzed descriptively. The survey method is employed as the main one of the research. Questionnaire and interview are chosen to collect the data. All the questions are written in participants' native language to avoid ambiguousness. This method is applied because of some reasons. Firstly, the researcher wants to know in which situations students are often reluctant to speak and the reasons why they keep silent. Secondly, the research focuses on finding which cultural or didactic factors can affect students' reticence. For this purpose, the researcher delivered the questionnaire to 60 first year students and sophomores among over 164 teacher-trainees of English. The subjects of the research count for approximately $37 \%$ of the population and most of them are female and come from different racial ethnicities and areas. The questionnaire is delivered to them randomly to enhance the diverse cultural backgrounds of the participants. For the sake of objectiveness in responding to the questionnaire, all the participants are asked to keep their names anonymous, and their answers are kept confidential for this research only. The interview is done with ten students with a view to finding how they interpret the issue of silence in class, their attitude towards the presence of the teacher during class discussion and how students' learning styles influence their reticence.

\section{RESULTS AND DISCUSSION}

The data collected from the questionnaire show that different students have different culture of learning. Some students are eager to speak in class, but the majority of the participants still show their reticence in various contexts and for a large number of reasons. The aim of the first two questions is to find out how they respond to the problems raised by the teacher in the class. The finding of the data is tabulated as follows Table 1 .

The data show that nearly half of the students are willing to express their ideas when they know the answers to their teachers' questions. On the contrary, more than $52 \%$ of them tend to keep silent and wait for the answers from the teachers when they are not sure of the answers. The fact also shows that even when knowing the answers to the problem, $36.8 \%$ of them rarely express their ideas in the class, let alone other cases. The findings above help the researcher find that the engagement of speaking of the students in the class does not depend on the knowledge they know, but also depend on different individuals' attitude.

Table 1: Students' responses to problems raised by their teachers

\begin{tabular}{|c|c|c|c|c|}
\hline \multirow[t]{2}{*}{$\begin{array}{l}\text { How they } \\
\text { respond in class }\end{array}$} & \multicolumn{2}{|c|}{$\begin{array}{l}\text { when they are not } \\
\text { sure of the } \\
\text { answers }\end{array}$} & \multicolumn{2}{|c|}{$\begin{array}{l}\text { when they are } \\
\text { sure of the } \\
\text { answers }\end{array}$} \\
\hline & $\begin{array}{l}\text { Number } \\
\text { of } \\
\text { response } \\
\mathrm{S}\end{array}$ & $\begin{array}{l}\text { Percen } \\
\text { tage }\end{array}$ & $\begin{array}{l}\text { Numb } \\
\text { er of } \\
\text { respon } \\
\text { ses }\end{array}$ & $\begin{array}{l}\text { Perce } \\
\text { ntage }\end{array}$ \\
\hline $\begin{array}{l}\text { Keeping silent } \\
\text { and waiting for } \\
\text { the answers from } \\
\text { the others }\end{array}$ & 11 & $19.3 \%$ & 3 & $5.3 \%$ \\
\hline $\begin{array}{l}\text { Keeping silent } \\
\text { and waiting for } \\
\text { the answers from } \\
\text { the teacher }\end{array}$ & 30 & $52.6 \%$ & 5 & $8.8 \%$ \\
\hline $\begin{array}{l}\text { Being willing to } \\
\text { express their } \\
\text { ideas }\end{array}$ & 6 & $10.5 \%$ & 28 & $\begin{array}{l}49.1 \\
\%\end{array}$ \\
\hline $\begin{array}{l}\text { Rarely expressing } \\
\text { their ideas }\end{array}$ & 10 & $17.5 \%$ & 21 & $\begin{array}{l}36.8 \\
\%\end{array}$ \\
\hline
\end{tabular}

To seek for the reasons of students' reticence in class, the researcher asks the participants to answer question number three, and the result is shown in table 2.

Table 2: Reasons why students keep silent when teachers raise questions

\begin{tabular}{|c|c|c|}
\hline Reasons & $\begin{array}{ll}\text { Number } & \text { of } \\
\text { responses } & \end{array}$ & Percentage \\
\hline $\begin{array}{l}\text { The learning } \\
\text { atmosphere of the } \\
\text { class }\end{array}$ & 11 & $19.3 \%$ \\
\hline $\begin{array}{l}\text { The students' } \\
\text { habits }\end{array}$ & 7 & $12.3 \%$ \\
\hline $\begin{array}{l}\text { Both of the above } \\
\text { reasons }\end{array}$ & 39 & $68.4 \%$ \\
\hline
\end{tabular}

The fact in table 2 shows that both students' learning habits and the class atmosphere can affect their reticence. In question number four, the researcher asks the participants whether they reason with their teachers about the right and the wrong of an issue. The data collected from the students' response is represented in table number 3 . 
Table 3: Student's reasoning with their teachers about the appropriateness of an issue.

\begin{tabular}{lll}
\hline Answers & $\begin{array}{l}\text { Number of } \\
\text { participants }\end{array}$ & Percentage \\
\hline Yes-Regularly & 3 & $5.3 \%$ \\
Yes-But rarely & 45 & $78.9 \%$ \\
No-Never & 9 & $15.8 \%$ \\
\hline
\end{tabular}

The high percentage of the students who rarely reason with their teachers about the right or the wrong of an issue can be explained more clearly by themselves as the reasons they provide in the questionnaire. They give a plenty of reasons for avoiding confronting the teacher. Nevertheless, the most frequent answers are to avoid misunderstandings, to show respects for the teacher because he or she may sometimes make a mistake, but in many cases their arguments turn out to be wrong after receiving explanation from their teachers. They also mean that in some cases they are right but they are afraid of the teacher's displeasing attitude towards them later on. Some of these reasons can lead to the students' loss of confidence in speaking publicly. Several students say

I rarely argue or reason with my teachers because many of them don't like this. They even say that I am a disrespectful student as "to teach my mother to suck eggs." Teachers rarely stand corrected. However, I am ready to argue if I know the information I say is exactly right.

However, very few students say that they never confront their teachers because there are only a few chances that students can show their reasoning in the class. If there are some, it is not easy for me to have a turn to speak.

Question number five shows how students deal with a confusing problem in class, and their answers and explanations are shown in table 4.

Table 4: How students solve a confusing problem in class

\begin{tabular}{lll}
\hline & $\begin{array}{l}\text { Number } \\
\text { response }\end{array}$ & $\begin{array}{l}\text { of } \\
\text { age }\end{array}$ \\
\hline $\begin{array}{l}\text { Asking the teacher } \\
\text { immediately in the class }\end{array}$ & 16 & $24.6 \%$ \\
$\begin{array}{l}\text { Keeping silent } \\
\text { Asking the teacher after the } \\
\text { class }\end{array}$ & 25 & $47.4 \%$ \\
\hline
\end{tabular}

Those who keep silent in case they have a confusing a problem explain that they do not want and even not dare to interrupt the teacher as well as not want to waste the class time. Also, they assert themselves in the questionnaire that nowadays it is easy to have access to the internet which will help them find the answer on their own. Another explanation is that they' $d$ rather consult their friends in order not to be humiliated in public.

The last question in the questionnaire requires the participants to choose the most three important issues to them among the five items provided. Then they were required to rank them in order of significance.

Table 5: Students rank the significance of class issue

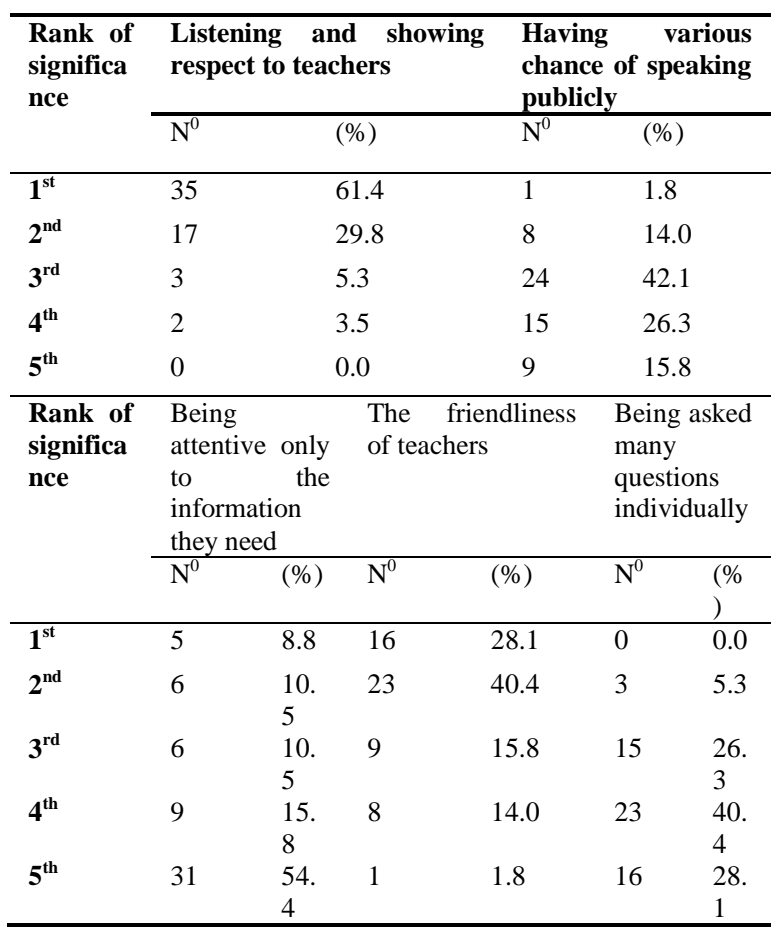

The data in table 5 shows that listening and showing respect to their teachers are considered to be the most important to the participants. The teacher's friendliness is also regarded as the most important to $28.1 \%$ in comparison with the $61.4 \%$ of the choice by other students for listening and showing respect to teachers. Only one student agreed that having many chances of speaking publicly as the most important issue, and no student has claimed to be asked question individually as the most significant to them. Moreover, students show very much interest in their teachers' friendliness by $40.4 \%$ which only ranks second after the most important issue mentioned above. More than half of the participants disagree that they only pay attention to the information of the lecture that they need. The 
result in table 5 also shows that students show their most concern about listening to teachers and the teachers' friendliness. However, students also desire to have various chances of speaking publicly. The percentage of 42.1 regarding it as the third important is the evidence for their desire.

During the interview, the researcher asked ten students individually with two following questions.

1. How do you feel about your group discussion without teachers? Why so?

2. What is your opinion of the saying "silence is gold."? How do you apply it in your learning in class?

There are some paradoxical ideas about students' group discussion without teachers. Most of the interviewees agree that they will freely discuss with enthusiasm when discussing problems within their groups without having to be authorized and supervised by teachers. Their opinions show that if the presence of their teachers can affect the atmosphere of the group discussion. This is a signal of how power distance can affect their reticence in class. However, they all say that teachers' feedback and participation in their discussion will make it more effective and even more motivating; otherwise the exciting atmosphere of the discussion makes them distracted. Similarly, in answer to the second questions, most of the interviewees opine that the saying "silence is gold." is good to apply in class because it helps teachers save time and that students do not risk losing their faces. Furthermore, they have more time to listen to the teacher's delivery of the lecture. Some of the participants also say that "remaining silent to the talkative is also a method." On the contrary, others say that "keeping silent is not really gold in class because it will make the class become boring and frustrate the teacher; but students' willingness to speak in class or not depends on how the teacher conducts the class."

\section{CONCLUSIONS}

The results in the data show that reticence in class come from many causes. The very first cause is students' lack of confidence, knowledge. The second cause is their personal beliefs and different culture of learning in an environment where there is large power distance between the teacher and the students. Many of them overemphasize the value of silence as gold. They consider it is a way to show respect to their teacher because some of them do not want or dare to contradict others publicly. The third reason comes from teachers' teaching method for the results of the findings show that in some situations students want to participate in the lesson orally, but whether they really speak out or not can depend on how the teacher manage the class. Oriental cultural identity, power distance, and collectivists' culture of teaching and learning are the leading factors that affect learners' reticence in Asian classes.

From the findings of this study, the following recommendations are made as follows lecturers may use the findings from research on students' reticence as a yardstick to better understand themselves and the students' needs for the betterment of the learning process. It is recommended that teachers create a friendly atmosphere, be mindful of their students' culture and psychology, and tactfully combine eclectic teaching methods in different teaching contexts. Allowing learners to work in small groups when attempting to answer a question and then provide feedback later is strongly recommended for the sake of offering them more exposure to have autonomous practical environment.

The following factors should also be taken professionally by the teacher in the class

1. Background knowledge

2. Competence and performance

3. Voice, Intonation

4. Dialog manner

5. Speed

6. Eye contact

7. Facial expression

8. Simple wording

9. Attentiveness to learners, giving instant

10. feedback

11. Sense of humor

12. Egalitarianism

13. Authentic and comprehensible input

14. Turn allocation

15. Flexibility

It is believed that there is no best teaching method. So it is the utmost importance that teachers are mindful of their different cultural teaching contexts.

\section{REFERENCES}

Allwright, R., Bailey, K. (1991). Focus on the language classroom: an introduction to classroom research for language teachers. Cambridge: Cambridge University Press.

Biggs, J. (1996). Western misconceptions of the Confucian-heritage learning culture. In David A. Watkins \& John B. Biggs (Eds.), The Chinese learner: Cultural, psychological, and contextual influences. Hong Kong: CERC and ACER. 45-67 
Chaudron, C. (1988) Second language classrooms: research on teaching and learning. New York: Cambridge University Press.

Cheng, X. (2000). Asian students' reticence revisited. System, 28, 435-446.

Dahl, S. (2003). An Overview of Intercultural Research, Society for Intercultural Training and Research UK I/10. Citing Internet sources URL http://www.unice.fr/crookall-cours/iup_cult/_ docs/_dahal\%20-\%20overview-of-interculturalresearch.pdf

Donald, C. (2010). Learning How To Speak: Reticence In The ESL Classroom. ARECLS, 7, 41-58.

Ferris, D., Tagg, T. (1996). Academic Listening/Speaking tasks for ESL students: Problems, Suggestions and Implication. TESOL Quarterly, 30(2), 297-230.

Johnson, E. (1997) Cultural norms affect oral communication in the classroom. New Directions for Teaching and Learning, 70, 47-52.

Hofstede, G. (1986). Cultural Differences in Teaching and Learning. International Journal of Intercultural Relations, 10, 301-320

Jones, J. (1999). From silence to talk: cross-cultural ideas on students' participation in accademic. English for Specific Purposes, 18(3), 241-259.

Keaten, J.A., Kelly, L., Finch, C. (2000). Effectiveness of the Penn State Program in Changing Beliefs Associated with Reticence. Communication Education, 49, 134145.

Li, H., Liu, Y. (2011, August). A Brief Study of Reticence in ESL Class. Theory and Practice in Language Studies, 1(8), 961-965.

Nunan, D. (1999). Second Language Teaching and Learning. Massachusetts: Heinle and Heinle.

Tsui, A.B.M. (1996). Reticence and anxiety in second language learning, Voices from the Language Classroom, Cambridge 1996, 145-167. 